\title{
Rapid Solvent Extraction of Gold(III) with High Molecular Weight Amine from Organic Acid Solution
}

\author{
$S S$ Kolekar and M A Anuse* \\ Analytical Chemistry Laboratory, Department of Chemistry, \\ Shivaji University, Kolhapur 416 004, India \\ E-mail:maanuse@usa.net
}

Received: 14 November 2000

\begin{abstract}
A novel solvent extraction separation method has been developed for the determination of gold in real samples. It involves selective and quantitative extraction of gold by $\mathrm{N}$-n-octylaniline, a high molecular weight amine (HMWA), in xylene from aqueous sodium malonate medium at $\mathrm{pH}$ 1.0. The effects of concentration of malonate, extractant, metal ion, and $\mathrm{pH}$ and of various diluents, stripping agents and other substances on the quantitative extraction of gold have been assessed. The applicability of the method to binary mixtures, synthetic mixtures, alloys and pharmaceutical samples is discussed.
\end{abstract}

The importance of gold in human life as well as its fascination for scientists has been appreciated right from alchemist times until the present day. This metal is found in about $3.5 \mathrm{ppb}$ in the earth's crust, often as $75-90 \%$ pure native gold that has been released by the weathering of sedimentary and igneous rocks. Gold is one of the most ancient metals used in the arts and jewellery, and it is of growing importance in technology because of its resistance to corrosion. It commands a premium price because of its low abundance in nature. The economy of a nation depends to a significant extent on the size of its gold reserves.

Many alloys used in dentistry contain gold, silver and copper, often with small amounts of platinum and palladium. The utility of gold or gold salts has been recognized since the time of Ayurveda, the ancient Indian medical science $(1500-1000 \mathrm{BC})$. In ancient Indian philosophy many remedial uses of gold in curing patients were described.

It is worthwhile here to stress the advantages of organic acid media over mineral acid media. One of the distinct advantages of the organic acid media is the facility of controlling the concentration of complexing ligand, the ease of adjustment of $\mathrm{pH}$ and the wide difference in $\mathrm{pH}$ at which various metals form anionic complexes. The comparative ease of stripping of the complexes from the organic phase can be achieved by fully exploiting the differences in reactivity of various metals to extraction back into the aqueous phase by mineral acid. It is known that organic acid media offer better separation of metals possibly due to high stability of metal-organic acid complexes.

The preconcentration of metals from complex matrices of natural samples obtained by using high molecular weight amine (HMWA) extractants is well known (1) but little work has been reported on the extraction of gold, particularly by secondary amines. However, the solvent extraction technique using HMWA and ammonium salts is effective for extracting gold. It is also effective for the separation of gold from other associated elements. Some HMWA have been used for extraction separation and determination of gold(III) from real samples. Adogen-464 (2) in carbon tetrachloride extracts gold(III) from $1.2 \mathrm{M} \mathrm{HCl}$ medium, with the method requiring $5 \mathrm{~min}$ for equilibration. The extraction of gold with trioctylamine (TOA), trioctylmethylammonium chloride [TOMA $(\mathrm{Cl})]$ and trioctylmethyl ammonium bromide [TOMA $(\mathrm{Br})]$ (3) from hydrochloric or hydrobromic acid solution has been carried out in combination with atomic absorption spectrometry. A 
preconcentration step is required since a low concentration of gold and chemical separations are usually necessary to avoid a matrix effect. Tri-iso-octylamine (4) has been used for extraction of gold from hydrochloric or hydrobromic acid media with direct measurement of the absorbance of the organic phase without following the stripping step. Pohlandt has reported the effectiveness of n-octylaniline $(5-9)$ as an extractant for noble metals. The extraction depends upon the method of preparation of the reagent. Some of the drawbacks of the method are (i) emulsion formation, (ii) requirement of more equilibration time $(30 \mathrm{~min})$, (iii) higher reagent concentration and (iv) the need for multiple extraction. Solvent extraction of gold(III) by the chloride salt of the tertiary amine Hostarex A 327 (10) in n-decane has been studied. The extraction reaction is found to be exothermic and the extraction equilibrium depends on the ionic strength. Methods have been developed for the extraction of gold(III) with phosphorus-containing extractants such as cyanex 923 (11), tributyl phosphate (12), phospholene (13) and also for sulphur-containing reagents such as ethyl thioacetoacetate (14), 2-mercaptobenzothiazole (15), thioethers (16) and sulfide podand 1,12-di-2theienyl-2,5, 8,11-tetrathiadodecane (17). Crown ethers (18) have also been used to increase the effectiveness of gold extraction into isobutyl methyl ketone but they require 5 min equilibration time.

$\mathrm{N}$-n-Octylaniline has been used in this laboratory for quantitative extraction of some platinum group metals $(19-22)$. The use of this reagent is found to be advantageous as it can be synthesised at low cost, with high yield and of best purity. The present investigation describes its use in establishing the conditions for the quantitative extraction of gold(III) and the development of a rapid and selective method for the separation of gold(III) from associated elements. The method has been evaluated for the separation and determination of gold(III) from alloys and pharmaceutical samples.

\section{EXPERIMENTAL}

\begin{abstract}
Apparatus
An Elico digital spectrophotometer, Model SL-171, with $1 \mathrm{~cm}$ quartz cells was used for absorbance measurements; $\mathrm{pH}$ measurements were carried out using an Elico digital pH meter model LJ-120.
\end{abstract}

\section{Reagents}

A stock solution of gold(III) was prepared by dissolving $1 \mathrm{~g} \mathrm{HAuCl}_{4}$ (A R, Johnson Matthey plc) in $250 \mathrm{~mL}$ of double distilled water and was standardised gravimetrically (23). A working solution was made therefrom by appropriate dilution.

$\mathrm{N}$-n-octylaniline was prepared by the method of Gardlund (24) and its solution (0.1 M) was prepared in xylene.

A $10 \%$ solution of stannous chloride dihydrate in $1 \mathrm{M}$ hydrochloric acid was used. A fresh solution should be prepared weekly.

All chemicals used were of A R grade. Doubly distilled water was used throughout.

\section{Procedure}

An aliquot of $2 \mathrm{~mL}$ of $\mathrm{Au}(\mathrm{III})$ solution $(100 \mu \mathrm{g} / \mathrm{mL})$ was

Table 1 Effect of Foreign Ions on the extraction of $200 \mu \mathrm{g}$ Gold(III) at pH 1.0 in 0.03M Sodium Malonate with 0.1M N-nOctylaniline Dissolved in Xylene

$\begin{array}{cc}\begin{array}{c}\text { Ratio of ions } \\ \text { (Gold : ions) }\end{array} & \text { Amount tolerated }(\mathbf{m g}) \\ \mathrm{I}: 125 & 25 \\ \mathrm{I}: 100 & 20 \\ \mathrm{I}: 75 & 15 \\ \mathrm{I}: 50 & 10 \\ \mathrm{I}: 25 & 5 \\ \mathrm{I}: 10 & 2 \\ \mathrm{I}: 5 & \mathrm{I} \\ \mathrm{I}: 2.5 & 0.5 \\ - & 0 \\ \mathrm{a}=\text { masked } \text { with tartrate } \quad \mathrm{b}=\text { masked with oxalate }\end{array}$

\section{Foreign ion}

$\mathrm{U}(\mathrm{VI})$ citrate, iodide, bromide, fluoride

$\mathrm{Ni}(\mathrm{II}), \mathrm{Ca}(\mathrm{II}), \mathrm{Ba}(\mathrm{II})$, tartrate, oxalate

$\mathrm{Mn}(\mathrm{II}), \mathrm{Mg}(\mathrm{II}), \mathrm{Cu}(\mathrm{II}), \mathrm{Be}(\mathrm{II}), \mathrm{Al}(\mathrm{III}), \mathrm{EDTA}$

$\mathrm{Fe}(\mathrm{III}), \mathrm{Cd}(\mathrm{II}), \mathrm{Pb}(\mathrm{II}), \mathrm{V}(\mathrm{V}), \mathrm{Ti}(\mathrm{IV}), \ln (\mathrm{III})$, acetate

$\mathrm{Fe}(\mathrm{II}), \mathrm{Bi}(\mathrm{III}), \mathrm{Mo}(\mathrm{VI}), \mathrm{Ce}(\mathrm{IV}), \mathrm{Te}(\mathrm{IV}), \mathrm{Sr}(\mathrm{II}), \mathrm{Sb}(\mathrm{III}), \mathrm{Cr}(\mathrm{VI})$, thiocyanate

$\mathrm{Hg}(\mathrm{II}), \mathrm{TI}(\mathrm{I})$

$\operatorname{Ir}(\mathrm{IV}), \mathrm{Rh}(\mathrm{III})^{\mathrm{a}}, \mathrm{Os}(\mathrm{VIII}), \mathrm{Se}(\mathrm{IV})$

$\operatorname{Pd}(I I)^{a}, \operatorname{Pt}(I V)^{b}$

Thiourea, ascorbate, thiosulphate 
Table 2 Separation of Gold(III) from Multicomponent Mixtures

\begin{tabular}{|c|c|c|c|c|}
\hline Metal ion & $\begin{array}{l}\text { Amount } \\
\text { taken, } \mu \mathrm{g}\end{array}$ & $\begin{array}{c}\text { Average } \\
\% \text { Recovery* }\end{array}$ & $\begin{array}{c}\text { Chromogenic } \\
\text { ligand }\end{array}$ & $\begin{array}{c}\text { Reference } \\
\text { number }\end{array}$ \\
\hline $\begin{array}{l}\mathrm{Au}(\mathrm{III}) \\
\mathrm{Pd}^{\mathrm{a}}(\mathrm{II})\end{array}$ & $\begin{array}{l}200 \\
100\end{array}$ & $\begin{array}{l}99.9 \\
99.8\end{array}$ & 4'-chloro PTPT & $(27)$ \\
\hline $\begin{array}{l}\mathrm{Au}(\mathrm{III}) \\
\mathrm{Pt}^{\mathrm{b}}(\mathrm{IV})\end{array}$ & $\begin{array}{l}200 \\
300\end{array}$ & $\begin{array}{l}99.9 \\
99.8\end{array}$ & $\mathrm{SnCl}_{2}$ & $(23)$ \\
\hline $\begin{array}{l}\mathrm{Au}(\mathrm{III}) \\
\operatorname{Ir}(\mathrm{IV})\end{array}$ & $\begin{array}{l}200 \\
100\end{array}$ & $\begin{array}{l}99.9 \\
99.8\end{array}$ & $\mathrm{SnCl}_{2}+\mathrm{HBr}$ & (26) \\
\hline $\begin{array}{l}\mathrm{Au}(\mathrm{III}) \\
\mathrm{Os}(\mathrm{VIII})\end{array}$ & $\begin{array}{l}200 \\
300\end{array}$ & $\begin{array}{l}99.8 \\
99.8\end{array}$ & Thiourea & (26) \\
\hline $\begin{array}{l}\mathrm{Au}(\mathrm{III}) \\
\mathrm{Rh}^{\mathrm{a}}(\mathrm{III})\end{array}$ & $\begin{array}{l}200 \\
300\end{array}$ & $\begin{array}{l}98.9 \\
99.7\end{array}$ & $\mathrm{SnCl}_{2}+\mathrm{KI}$ & (26) \\
\hline $\begin{array}{l}\mathrm{Au}(\mathrm{III}) \\
\mathrm{Ru}(\mathrm{III})\end{array}$ & $\begin{array}{l}200 \\
300\end{array}$ & $\begin{array}{l}99.7 \\
99.7\end{array}$ & Thiourea & (26) \\
\hline $\begin{array}{l}\mathrm{Au}(\mathrm{III}) \\
\mathrm{Se}(\mathrm{IV})\end{array}$ & $\begin{array}{l}200 \\
300\end{array}$ & $\begin{array}{l}99.8 \\
99.8\end{array}$ & 4'-bromoPTPT & $(28)$ \\
\hline $\begin{array}{l}\mathrm{Au}(\mathrm{III}) \\
\mathrm{Te}(\mathrm{IV})\end{array}$ & $\begin{array}{l}200 \\
100\end{array}$ & $\begin{array}{l}99.9 \\
99.7\end{array}$ & 4'-bromo PTPT & (29) \\
\hline $\begin{array}{l}\mathrm{Au}(\mathrm{III}) \\
\mathrm{Fe}(\mathrm{III})\end{array}$ & $\begin{array}{r}200 \\
10,000\end{array}$ & $\begin{array}{l}99.9 \\
99.8\end{array}$ & Thiocyanate & (26) \\
\hline $\begin{array}{l}\mathrm{Au}(\mathrm{III}) \\
\mathrm{Cu}(\mathrm{II})\end{array}$ & $\begin{array}{r}200 \\
15,000\end{array}$ & $\begin{array}{l}99.8 \\
99.9\end{array}$ & 4'-chloro PTPT & (30) \\
\hline $\begin{array}{l}\mathrm{Au}(\mathrm{III}) \\
\mathrm{Co}(\mathrm{II})\end{array}$ & $\begin{array}{r}200 \\
15,000\end{array}$ & $\begin{array}{l}99.9 \\
99.8\end{array}$ & Thiocyanate & (3I) \\
\hline $\begin{array}{l}\mathrm{Au}(\mathrm{III}) \\
\mathrm{Ni}(\mathrm{II})\end{array}$ & $\begin{array}{r}200 \\
20,000\end{array}$ & $\begin{array}{l}99.7 \\
99.9\end{array}$ & DMG & (3I) \\
\hline
\end{tabular}

mixed with a sufficient quantity of sodium malonate $(0.111 \mathrm{~g})$ to make its concentration $0.03 \mathrm{M}$ in a total volume of $25 \mathrm{~mL}$ of the solution. Then the $\mathrm{pH}$ of the solution was adjusted to 1.0 using dilute hydrochloric acid and sodium hydroxide. The solution was transferred into a $125 \mathrm{~mL}$ separation funnel and shaken with $10 \mathrm{~mL}$ of $0.1 \mathrm{M}(2.303 \%) \mathrm{N}$-n-octylaniline in xylene for $1 \mathrm{~min}$. After equilibration, the mixture was allowed to separate and the metal was stripped from the organic phase with two $10 \mathrm{~mL}$ portions of ammonia solution $(7 \mathrm{M})$. The extracts were evaporated to moist dryness. The residue was dissolved in $5 \mathrm{~mL}$ aqua regia, evaporated, then $2 \mathrm{~mL}$ of $2 \%$ sodium chloride solution (23) and concentrated hydrochloric acid were added and the mother liquor again evaporated. The procedure of evaporation was repeated to remove oxides of nitrogen, taking care not to evaporate to dryness and so avoid loss of gold (25). The residue was dissolved in $0.05 \mathrm{M}$ hydrochloric acid and the gold(III) determined spectrophotometrically by stannous chloride method (26) at $400 \mathrm{~nm}$.

\section{RESULTS AND DISCUSSION}

\section{Extraction as a Function of $p H$}

The extraction of gold(III) was carried out from 0.03 $\mathrm{M}$ sodium malonate at $\mathrm{pH}$ varying from $0.1-10.0$. The extraction commenced at $\mathrm{pH} 0.1(42 \%)$ and was quantitative between $\mathrm{pH} 0.5-2.0$. This shows that the equilibrium in the $\mathrm{pH}$ range $0.5-2.0$ is favourable for the formation of an ion-pair complex. If a higher $\mathrm{pH}$ is used for the extraction there is the possibility of hydrolysis. This indirectly promotes competing equlibria with the formation of an ion pair complex, resulting in a decrease in extraction effectiveness. 
Extraction as a Function of $\mathrm{N}$-n-Octylaniline and Organic Acid Concentration

The gold(III) was extracted at $\mathrm{pH} 1.0$ with varying concentrations of N-n-octylaniline at constant $(0.03 \mathrm{M})$ sodium malonate concentration. The concentration was varied from $0.005 \mathrm{M}$ to $0.15 \mathrm{M}$ of extractant in xylene. The extraction was $49 \%$ with $0.005 \mathrm{M}$ of extractant but was quantitative in the range of $0.08 \mathrm{M}-0.15 \mathrm{M}$ of $\mathrm{N}-\mathrm{n}$ octylaniline. With increased concentration of extractant there was a decrease in the proportion of gold(III) extracted and this might be due to the dissociation of the complex. We used $0.1 \mathrm{M}$ of the extractant for routine work.

The extraction of gold(III) was carried out at $\mathrm{pH} 1.0$ with $0.1 \mathrm{M} \mathrm{N}$-n-octylaniline in xylene in the presence of varying concentrations of sodium malonate and sodium succinate as weak acid media. The extraction commenced with $0.005 \mathrm{M}$ sodium malonate and became quantitative in the concentration range $0.02 \mathrm{M}-0.04 \mathrm{M}$ sodium malonate. With an increased concentration of sodium malonate there is a decrease in the efficiency of extraction of gold(III). The decrease in extraction at high acid concentration is presumably due to preferential formation of the malonate of the N-n-octylaniline. A $0.03 \mathrm{M}$ concentration of sodium malonate was therefore used throughout this work. Extraction was found to be incomplete in sodium succinate media.

\section{Choice of Diluents}

Keeping all of the other variables constant, the gold(III) was extracted with $0.1 \mathrm{M} \mathrm{N}$-n-octylaniline with various diluents. The extraction was quantitative with xylene, amyl acetate, amyl alcohol and n-butyl alcohol as the diluents. It was incomplete with benzene (34\%), toluene $(28 \%)$, chloroform (36\%), carbon tetrachloride (30\%) and methyl isobutyl ketone (MIBK) (36\%). An inert diluent such as xylene does not participate in the actual extraction process as do the oxygenated solvents. $\mathrm{N}$-n-octylaniline causes ion-pair formation of a goldmalonate complex and thus promotes extraction. However, a definite correlation between diluent and its dielectric constant could not be established.

\section{Nature of the Extracted Species}

The probable composition of extracted species is ascertained by plotting graphs of $\log \mathrm{D}_{\text {[Au(III)] }}$ against $\log$ $\mathrm{C}_{[\mathrm{N}-\mathrm{n} \text {-octylaniline] }}$ at fixed sodium malonate concentration $(0.03 \mathrm{M})$. The plots were linear, having the slopes of 1.24 and 1.04 respectively (at $\mathrm{pH} 0.75,1.0$ ). Also, plots of $\log$ $\mathrm{D}_{[\mathrm{Au}(\mathrm{III})]}$ against $\log \mathrm{C}_{[\text {malonate] }}$ at fixed $\mathrm{N}$-n-octylaniline concentration $(0.1 \mathrm{M})$, were linear and with slopes of 2.05 and 1.87 respectively. The probable composition of the extracted species is calculated to be 1:2:1 (metal : acid
: extractant). The possible mechanism for the extracted species appears to be protonated $\mathrm{N}$-n-octylaniline which forms cationic species as $\mathrm{RR}^{\prime} \mathrm{NH}_{2}{ }^{+}$while malonate combines with gold(III) to form anionic species as $\mathrm{Au}\left(\mathrm{C}_{3} \mathrm{H}_{2} \mathrm{O}_{4}\right)_{2}{ }^{-}$and both of them associate to form an ion pair of the type $\left[\mathrm{RR}^{\prime} \mathrm{NH}_{2}{ }^{+} \cdot \mathrm{Au}\left(\mathrm{C}_{3} \mathrm{H}_{2} \mathrm{O}_{4}\right)_{2}{ }^{-}\right]_{\text {org }}$ and since these are neutral they are extractable species.

Gold(III) was stripped from the organic phase with various stripping agents such as acids, bases, salts and buffer solutions. It was then found that with $>3 \mathrm{M}$ ammonia the stripping was quantitative because beyond this molarity the optimum conditions of extraction were reversed. Hence $7 \mathrm{M}$ ammonia was used as the stripping agent.

It was found that the extraction of gold(III) was quantitative when the aqueous to organic phase volume ratio was in the range $1: 1$ to $5: 1$, while it decreased when the ratio changed from 5:1 to 20:1. Hence, the aqueous to organic volume ratio recommended in the procedure is $2.5: 1$.

Variation of the shaking period showed that a $15 \mathrm{~s}$ equilibration time was adequate for quantitative extraction of gold(III) from malonate media. But in our work, 1 min equilibration time was recommended in order to ensure the complete extraction of gold(III). However, a prolonged equilibration period ( $>5 \mathrm{~min}$ ) was found to have an adverse effect on the extraction and should be avoided.

The loading capacity was found to be $5 \mathrm{mg}$ of gold(III) with $10 \mathrm{ml}$ of $0.1 \mathrm{M} \mathrm{N}$-n-octylaniline in xylene at $0.03 \mathrm{M}$ sodium malonate concentration.

\section{Effect of Foreign Ions}

Gold(III) was extracted in the presence of other ions and substances (see Table 1). The tolerance limit was set as the amount of foreign ion required to cause $\pm 2 \%$ error in the recovery of gold. The only species showing interference in the procedure were thiourea, ascorbate and thiosulphate. Of the cations examined, only $\mathrm{Pd}(\mathrm{II}), \mathrm{Rh}(\mathrm{III})$ and $\mathrm{Pt}(\mathrm{IV})$ interfered. The interference of $\mathrm{Pd}(\mathrm{II})$ and $\mathrm{Rh}(\mathrm{III})$ was eliminated by masking with tartaric acid and that of $\mathrm{Pt}(\mathrm{IV})$ with oxalic acid.

\section{APPLICATIONS}

\section{Separation of Gold(III) from Associated Metals}

Gold(III) was separated from commonly associated metal ions by taking advantage of the differences in the extraction conditions between metals.

Gold(III) was separated from Ir(III), Os(VIII), $\mathrm{Ru}(\mathrm{III}), \mathrm{Se}(\mathrm{IV}), \mathrm{Te}(\mathrm{IV})$ and base metals such as $\mathrm{Fe}(\mathrm{III})$, 
$\mathrm{Co}(\mathrm{II}), \mathrm{Ni}(\mathrm{II}), \mathrm{Cu}(\mathrm{II})$ by its extraction with $0.1 \mathrm{M} \mathrm{N}$-noctylaniline in xylene at $\mathrm{pH} 1.0$ from $0.03 \mathrm{M}$ sodium malonate media. Under these conditions all added metal ions remain quantitatively in the aqueous phase in which they are determined spectrophotometrically by standard methods (Table 2). Gold(III) from the organic phase was stripped with $(2 \times 10 \mathrm{~mL}) 7 \mathrm{M}$ ammonia and estimated spectrophotometrically by applying with stannous chloride method.

Gold(III) is separated from $\operatorname{Pd}(\mathrm{II})$ and $\mathrm{Rh}(\mathrm{III})$ by masking with each of $20 \mathrm{mg}$ of sodium potassium tartrate and that of $\mathrm{Pt}(\mathrm{IV})$ with $20 \mathrm{mg}$ of oxalic acid respectively. The masked metal ion from the aqueous phase is subsequently demasked and estimated by following a standard procedure. Gold from the organic phase was stripped with $7 \mathrm{M}$ ammonia and estimated using a recommended procedure.

The determination of small amounts of gold in mineral containing large amounts of base metals is difficult, hence it was decided in the present work to evaluate the effectiveness of $\mathrm{N}$-n-octylaniline as an extractant for the gold from the variety of the minerals and processed solutions. It was found that gold(III) was separated from comparatively large amounts of iron(III), cobalt(II), nickel(II) and copper(II) by its extraction with $0.1 \mathrm{M} \mathrm{N}$-n-octylaniline in xylene at $\mathrm{pH} 1.0$ from $0.03 \mathrm{M}$ malonate media. Under these conditions, all the base metals remain quantitatively in the aqueous phase, where they were determined using spectrophotometric methods.

\section{Determination of Gold(III) in a Synthetic Mixture}

A solution containing $200 \mu \mathrm{g}$ of gold(III) was taken and known amounts of other metals were added. Extraction of gold(III) was carried out using the method developed here. The results obtained were in good agreement with the amounts added (Table 3).

\section{Determination of Gold(III) in Real Alloys}

Dissolution of copper-silver-gold alloy - About $1 \mathrm{~g}$ of sample was transferred into a $250 \mathrm{ml}$ conical flask covered with a short-stem funnel and dissolved in $10 \mathrm{~mL}$ aqua regia. The solution was then treated with $10 \mathrm{~mL}$ of concentrated hydrochloric acid, added in $2 \mathrm{~mL}$ portions, the solution was evaporated almost to dryness on a steam bath after each addition. The residue was dissolved in dilute hydrochloric acid and the precipitated silver chloride filtered off and washed with dilute hydrochloric acid. The filtrate and washings were collected in a $250 \mathrm{~mL}$ standard flask and made up to volume with distilled water.

An aliquot of the sample solution was taken and gold(III) was determined using the procedure described above. The results of analysis are given in Table 4.
Table 3 Separation of Gold(III) from Synthetic Mixtures

\begin{tabular}{|c|c|c|c|c|}
\hline $\begin{array}{c}\text { Composition, } \\
\mu \mathrm{g}\end{array}$ & $\begin{array}{r}\text { Gold(III) } \\
\text { found } \mu \mathrm{g}\end{array}$ & Mean & $\begin{array}{c}\text { Recovery } \\
\%\end{array}$ & $\begin{array}{c}\text { RSD } \\
\%\end{array}$ \\
\hline $\begin{array}{l}\mathrm{Au}, 200 ; \mathrm{Pd}^{\mathrm{a}}, 200 ; \\
\mathrm{Pt}^{\mathrm{b}}, 200\end{array}$ & $\begin{array}{l}199.9 \\
199.8 \\
199.9 \\
199.9 \\
199.9\end{array}$ & 199.88 & 99.94 & 0.06 \\
\hline $\begin{array}{l}\mathrm{Au}, 200 ; \mathrm{Pd}^{\mathrm{a}}, 200 \\
\text { Co, } 1000 ; \mathrm{Ni}, 1000\end{array}$ & $\begin{array}{l}199.8 \\
199.8 \\
199.7 \\
199.8 \\
199.8\end{array}$ & 199.78 & 99.89 & 0.11 \\
\hline $\begin{array}{l}\mathrm{Au}, 200 ; \mathrm{Pd} \mathrm{d}^{\mathrm{a}}, 200 \\
\mathrm{Pt}^{\mathrm{b}}, 200 ; \mathrm{Ag}, 200\end{array}$ & $\begin{array}{l}199.9 \\
199.9 \\
199.8 \\
199.8 \\
199.9\end{array}$ & 199.86 & 99.93 & 0.07 \\
\hline $\begin{array}{l}\mathrm{Au}, 200 ; \mathrm{Se}, 300 \\
\text { Te, } 100\end{array}$ & $\begin{array}{l}199.8 \\
199.9 \\
199.9 \\
199.9 \\
199.9\end{array}$ & 199.88 & 99.94 & 0.06 \\
\hline $\begin{array}{l}\mathrm{Au}, 200 ; \mathrm{Fe}, 1000 \\
\mathrm{Cu}, 1000\end{array}$ & $\begin{array}{l}199.9 \\
199.9 \\
199.8 \\
199.9 \\
199.8\end{array}$ & 199.86 & 99.93 & 0.07 \\
\hline
\end{tabular}

Determination of Gold(III) from Ayurvedic Sample The sample (one tablet) was dissolved in $10 \mathrm{~mL}$ aqua regia. The solution was slowly evaporated to moist dryness, the residue dissolved in dilute hydrochloric acid, and the solution filtered if necessary. The filtrate

Table 4 Analysis of Alloys

\begin{tabular}{lcccc}
$\begin{array}{c}\text { Composition } \\
\text { of Alloy }\end{array}$ & $\begin{array}{c}\text { Gold(III) } \\
\text { found by } \\
\text { AAS \% }\end{array}$ & $\begin{array}{c}\text { Gold(III) } \\
\text { found by } \\
\text { proposed } \\
\text { method*\% }\end{array}$ & $\begin{array}{c}\text { Recovery } \\
\%\end{array}$ & $\begin{array}{c}\text { RSD } \\
\%\end{array}$ \\
$\begin{array}{l}\mathrm{Cu}, 49.35 ; \mathrm{Ag}, 7.25 ; \\
\mathrm{Au}, 43.4\end{array}$ & 43.3 & 43.2 & 99.8 & 0.23 \\
$\begin{array}{l}\mathrm{Cu}, 35 ; \mathrm{Ag}, 5 ; \\
\mathrm{Au}, 60\end{array}$ & 59.9 & 59.7 & 99.7 & 0.33 \\
\hline
\end{tabular}

* Average of five determinations 
Table 5 Analysis of Gold(III) in Ayurvedic Samples

$\begin{array}{lc}\text { Name of Medicine } & \begin{array}{c}\text { Amount found } \\ \text { by AAS, } \mu \mathrm{g} / \mathbf{m L}\end{array} \\ \begin{array}{l}\text { Vita-Ex-Gold } \\ \text { (Shree Baidyanath, Nagpur) }\end{array} & 80 \\ \begin{array}{l}\text { Suvarna Sootashekhar } \\ \text { (Ayurveda Rasashala, Pune) }\end{array} & 40 \\ \begin{array}{l}\text { Makardhwaja Vati } \\ \text { (Ayurveda Rasashala, Pune) }\end{array} & 36 \\ * \text { Average of five determinations } & \end{array}$

was diluted to $25 \mathrm{~mL}$ with distilled water. An appropriate aliquot of the solution was used for analysis. The amount of gold(III) found in the tablets is in agreement with the certified values given (Table 5). The accuracy of the results was confirmed using atomic absorption spectroscopy (AAS).

\section{ACKNOWLEDGEMENT}

The authors thank Dr K J Patil, Professor and Head of Department for his help and inspiration in the research work.

\section{ABOUT THE AUTHORS}

Sanjay S Kolekar is a senior research fellow studying for his Ph.D. in the field of solvent extraction of noble metals. He is currently working as the Head of the Chemistry Department, Sangola College, Sangola (India). He is a fellow of the Indian Science Congress Association, the Indian Chemical Society and the Indian Council of Chemists. His research interest is in the field of environmental chemistry, especially in the analysis of toxic metals.

Mansing A Anuse is a reader in chemistry at Shivaji University, Kolhapur (India) where he has been for 15 years. He has 18 years teaching experience in undergraduate and postgraduate departments. His fields of research interest are solvent extraction separation, spectrophotometry and environmental chemistry. $\mathrm{He}$ is author of 25 research papers in international journals such as Talanta, Analytical Letters and Separation Science \& Technology: they describe methods for the analysis of toxic, heavy, refractory and noble metals.

\section{REFERENCES}

G. Green, Talanta, 1973, 20, 139
S. Biswas, H.K. Mondal and S. Basu, Indian J. Chem., 1996, 35A, 804

\section{Amount found by \\ proposed method* $\mu \mathrm{g} / \mathrm{mL}$}

79.8

RSD \%

0.25

39.8

35.9

0.28
3 I. Tsukahara and M. Tanaka, Talanta, 1980, 27, 655

4 M.Y. Mirza, Talanta, 1980, 27, 101

5 A.A. Vasilyeva, I.G. Yudelevich, L.M. Gindin, T.V. Lankina, R.S. Shulman, I.L. Kotlarevsky and V.N. Andrievsky, Talanta, 1975, 22, 745

6 C. Pohlandt, Nat. Inst. Metallurgy, Randburg, S. Afr. Rept. No.1881 (1977)

7 C. Pohlandt, M. Hegetschweller, Nat. Inst. Metallurgy, Randburg; S. Afr. Rept. No. $1940(1978)$

8 C. Pohlandt, Talanta, 1979, 26, 199

9 R.N. Gedye, J. Bozic, P.M. Durbano and B. Williamson, Talanta, 1989, 36, 1055

10 S. Martinez, A.M. Sastre and F.J. Alguacil, Hydrometallurgy, 1999, 52, 63

11 E. Alguacil, C. Caravaca and S. Martinez, J. Chem. Technol. Biotechnol., 1998, 72, 339

12 J. Chen, L. Zhu, Y. Jing, X. Pang and K. Huang, Precious Met., 1998, 22, 65

13 A. Madi, N. Miralles, J. Cortina, J. Arnaldos and A. Sastre, Value Adding Solvent Extr (Pap. ISEC 1996), 1996, 1, 463

14 S.Z. Khan and Z.R. Turel, J. Radioanal. Nucl. Chem. Letters, 1985, 93(3), 125

15 M. Rajadhyaksha and Z.R. Turel, J. Radio Anal. Nucl. Chem. Letters, 1985, 96(3), 293

16 A. Ohki and M. Takazi, Anal. Chim. Acta, 1984, 159, 245

17 E. Lachowicz and M. Czapiuk, Talanta, 1990, 37, 1011

18 G.S. Vasilikiotis, I.N. Papadoyannis and TH.A. Kouimtzis, Microchem. J., 1984, 29, 356

19 T.N. Lokhande, M.A. Anuse and M.B. Chavan, Talanta, 1998, 46, 163

20 T.N. Lokhande, M.A. Anuse and M.B. Chavan, Talanta, 1998, 47, 823

21 T.N. Lokhande, G.B. Kolekar, M.A. Anuse and M.B. Chavan, Sep. Sci. Technol., 2000, 35, 153

22 T.N. Lokhande and M.A. Anuse, J. Saudi Chem. Soc., 2000, 4(1) 1

23 F.E. Beamish and J.C. Van Loan, 'Analysis of Noble Metals : Overview and Selected Methods', Academic Press Inc (London) Ltd., 1977, pp 128

24 Z.G. Gardlund, R.J. Curtis and G.W. Smith, Liquid Crystals Ordered Fluids, 1973, 2, 541

25 K.Z. Beyermann, Anal. Chem., 1964, 200, 183

26 E.B. Sandell, 'Colorimetric Determination of Traces of Metals', 3rd Ed. Interscience, New York, 1965, pp 503, 519, 702, 774, 781, 524

27 M.A. Anuse and M.B. Chavan, Chem. Anal. (Warsaw), 1984, 29, 409

28 G.B. Kolekar and M.A. Anuse, Research J. Chem. Environ., 1998, 2(3), 9

29 G.B. Kolekar and M.A. Anuse, Bull. Chem. Soc. Jpn, 1998, 71, 859

30 M.A. Anuse, S.R. Kuchekar and M.B. Chavan, Indian J. Chem.,1986, 25A, 1041

31 Zygmunt Marczenko, 'Spectrophotometric Determination of Elements', Ellis Horwood Limited, Chichester, 1976, pp 229, 370 